\title{
DNA flow-cytometric analysis of testicular germ cell populations of the bonnet monkey (Macaca radiata) as a function of sexual maturity*
}

\author{
G. R. Aravindan, N. Ravindranath, K. Gopalakrishnan $\dagger$ and \\ N. R. Moudgal \\ Primate Research Laboratory and Center for Advanced Research in Reproductive Biology, \\ Department of Biochemistry, Indian Institute of Science, Bangalore 560 012, India; and \\ $\dagger$ Institute for Research in Reproduction Parel, Bombay 400 012, India
}

\begin{abstract}
Summary. Testicular germ cell populations of biopsies from 32 male bonnet monkeys in 5 different age groups were quantitated in a flow cytometer after labelling of germ cell DNA with the specific fluorochrome, 4,6-diamidino phenyl indole. The 5 quantifiable populations were spermatogonia $(2 \mathrm{C})$, preleptotene spermatocytes (S phase), primary spermatocytes $(4 \mathrm{C})$, round spermatids (1C) and elongate spermatids $(\mathrm{HC})$. The seminiferous tubules of immature 3-4-year-old monkey had only Sertoli cells and spermatogonia $(2 \mathrm{C})$.

At 5-6 years, germ cells in S-phase $(9 \cdot 5 \%), 4 \mathrm{C}(11 \cdot 1 \%), 1 \mathrm{C}(41 \cdot 8 \%)$ and $\mathrm{HC}$ $(17 \cdot 1 \%)$ stages of maturation appeared for the first time but at 7-8 years of age and beyond all cell types except $\mathrm{HC}$ decreased while $1 \mathrm{C}$ remained relatively constant. Histometric analysis correlated well with the flow-cytometric data. The decrease in cells of $2 \mathrm{C}$, S-phase and $4 \mathrm{C}$ stages was associated with an increase in mitotic index, signifying acceleration in the kinetics of germ cell transformation into subsequent cell types. The total turnover in cell transformation $(1 \mathrm{C}: 2 \mathrm{C})$ was significantly $(P<0.01)$ increased at and beyond 7-8 years. Maximum transition from $2 \mathrm{C}$ to $4 \mathrm{C}$ occurred at 5-6 years $(4 \mathrm{C}$ : $2 \mathrm{C}$ ratio 0.8 at $5-6$ years and 0.6 at $7-8$ years). The ratio $\mathrm{HC}: 1 \mathrm{C}$ (kinetics of cell transformation during spermiogenesis) attained near total efficiency only by 10 years of age ( 1.08 at $10-14$ years; 0.9 at $18-20$ years). Also, the cell associations within the seminiferous tubules of monkeys $\geqslant 10$ years of age were better defined than those of younger animals.

The changes in germ cell ratios correlated well with alterations in testicular volume, sperm numbers in the ejaculate and surges of testosterone and increments in FSH in the serum, characteristic of development of sexual maturity. It is apparent from this study that DNA flow cytometry of testicular germ cell populations reveals subtle changes in spermatogenic status of bonnet monkeys with a high degree of sensitivity.
\end{abstract}

Keywords: spermatogenesis; DNA flowcytometry; germ cells; testosterone; FSH; puberty; primate

\section{Introduction}

Spermatogenesis is conventionally evaluated by carrying out time consuming and painstaking histological examination of testicular biopsies (Clausen et al., 1978a). The use of DNA flow cytometry, in contrast, facilitates rapid and accurate quantitation of large numbers of testicular

\footnotetext{
*Reprint requests: Professor N. R. Moudgal, Department of Biochemistry, Indian Institute of Science, Bangalore
} 560012 , India. 
germ cells and hence is gaining acceptance as an effective method of assessing spermatogenesis. Although flow-cytometric analyses of human testicular germ cell populations have been reported, they are for tissues obtained at autopsy (Thorud et al., 1980) or to investigate infertility (Clausen \& Abyholm, 1980; Evenson \& Melamed, 1983), and systematic studies have been confined to the mouse (Toppari et al., 1988) and the rat (Clausen et al., 1978a, b, 1979, 1982; Toppari et al., 1986; Van Kroonenburgh et al., 1986). Testicular germ cell populations of monkeys have not so far been measured by DNA flow cytometry.

Much basic information is available regarding the reproductive cycle of the female non-human primate (Prahalada et al., 1975; Maneckjee et al., 1976; Knobil, 1980; diZerega \& Hodgen, 1980; Ravindranath \& Moudgal, 1987), but relatively less is known about the regulation of the spermatogenic cycle in the male non-human primate (Bercu et al., 1983). The present studies were carried out to obtain baseline values for percentages of testicular germ cell types of bonnet monkeys as a function of age and to establish their correlation with histometric analysis of testicular biopsies, physiological attributes and endocrine profiles characteristic of sexual maturity.

\section{Materials and Methods}

Most of the monkeys used in this study were born in the colony and whenever wild-caught monkeys were added to a specific group to make up the required numbers, their age was determined by comparing their dentition with that of colony-born monkeys of similar age. The 32 males used were divided into 5 groups based on their age: pre-pubertal (3-4 years), pubertal (5-6 years), young adults (7-8 years), normal adults ( $10-14$ years) and older adults (18-20 years). All monkeys were maintained in well ventilated rooms with a regulated light:dark schedule (lights on for 12:00 h). Blood was taken from unanaesthetized monkeys by femoral venepuncture into Vacutainer tubes at 10:00 h and $22: 00 \mathrm{~h}$ to determine the occurrence of nocturnal testosterone surges. The standardized animal management practices followed in the colony have been published elsewhere (Ravindranath \& Moudgal, 1987).

Hormones and chemicals. Pepsin, Tween-20 and polyethylene glycol (PEG) were obtained from Sigma Chemical Co. (St Louis, MO, USA); 4,6-diamidinophenylindole (DAPI) from Serrafein Biochemica (Heidelberg, FRG); Dulbecco's phosphate-buffered saline (PBS) from Himedia (Bombay, India); the nylon filter, Nybolt P-25 from Swiss Silk (Zurich, Switzerland); ketamine hydrochloride from Parke-Davis (Detroit, MI, USA); crystalline testosterone from Steraloids, Inc. (NH, USA); and tritiated testosterone from Amersham Laboratories (Amersham, Bucks, UK).

Testicular biopsies and cell preparation. Approximately $100 \mathrm{mg}$ testicular tissue were removed from one testis of each monkey, anaesthetized with ketamine hydrochloride, and transferred to Petri dishes containing PBS. While a portion of the tissue was fixed in Karnovsky's fluid for eventual histometric analysis, the remainder was finely minced (Evenson \& Melamed, 1983) in a small volume of PBS and the preparation was vortexed to maximize the release of germ cells from seminiferous tubule minces. This procedure revealed germ cell ratios similar to those obtained from other attempted procedures using collagenase or trypsin. Subsequent fractions of cells recovered from the minced tubule debris, after the collection of the first fraction, exhibited decreased total cell yield but unchanged ratios, validating the fact that this procedure did not affect specific cell type losses. The cell suspension was aspirated, washed with PBS, filtered using nylon filter $(50 \mu \mathrm{m})$ and fixed in $70 \%$ chilled ethanol and stored at $4^{\circ} \mathrm{C}$ until analysis.

DNA staining and flow cytometry. The staining procedure followed was as described by Otto et al. (1981). Briefly, the fixed cells were washed with $0.9 \%(\mathrm{w} / \mathrm{v}) \mathrm{NaCl}$ and incubated with $0.5 \%$ pepsin in isotonic $\mathrm{PBS}(\mathrm{pH} 2.0)$ for I h at $37^{\circ} \mathrm{C}$. After centrifugation, the cells, by now rendered permeable to the stain, were resuspended in I volume of $0.2 \mathrm{M}-$ citric acid $(\mathrm{pH} 1.8)$ containing $0.5 \%$ Tween- 20 and $1 \%$ PEG and allowed to stand for $20 \mathrm{~min}$ at room temperature. Nine volumes of $5 \mu \mathrm{M}$-4,6-diamidino phenyl indole (DAPI) in $0.4 \mathrm{M}$-disodium-hydrogen-phosphate ( $\mathrm{pH} 9 \cdot 0$ ) were added (final $\mathrm{pH} \mathrm{7.4)}$ and incubated at room temperature in the dark for $30 \mathrm{~min}$. The stained cells were filtered through a nylon filter $(50 \mu \mathrm{m})$ and analysed in a Phywe ICP-22 (Phywe A.G., Gottingen, West Germany) flow cytometer, equipped with a high-pressure mercury lamp, at $700 \mathrm{~V}$, using filters of $360 \mathrm{~nm}$ wavelength for excitation and $450 \mathrm{~nm}$ for emission. Although the germ cell ratios measured by flow cytometry did not alter irrespective of whether 10 or 50000 cells were studied, for the purpose of this study, at least 50000 cells were analysed. The different cell populations thus obtained based on their DNA content (as opposed to ploidy expression, $\mathrm{N}$ ) are expressed as ' $\mathrm{C}$ ' values. A sample of human peripheral blood leucocytes was used as the diploid DNA standard (2C) to ascertain peak positions of the flow-cytogram distributions of populations and the cell in each peak were measured by planimetry (Otto et al., 1984).

Histometric analysis. Testicular biopsies were obtained from monkeys and fixed in modified Karnovsky's fluid (David et al., 1973), washed in $0.1 \mathrm{M}$-cacodylate buffer and post-fixed in $1 \%$ osmium tetroxide in $0.1 \mathrm{M}$-cacodylate buffer, dehydrated through graded series of acetone and embedded in araldite. Semithin sections of $0.5 \mu \mathrm{m}$ thickness were cut at frequent intervals and stained with toluidine blue and observed under bright-field optics. The tubular 
sections of the testicular biopsy were evaluated systematically and scored according to the method of Johnsen (1970). The score was given according to the presence or absence of the main cell types observed. The counting was performed with $\times 10$ objective exposing several tubules in one field. Damaged tubules were not included. The testicular biopsy scoring was done by the same observer. The mean score was calculated by multiplying the number of tubules recorded at each score with the score and the sum of all multiplications was divided by total number of tubules recorded. The total number of tubules recorded per biopsy was 50 .

Seminiferous tubules were examined by optical microscopy using a $\times 100$ oil-immersion objective and about 200 randomly distributed germ cells were counted; the number of dividing germ cells was divided by number of non-dividing germ cells to give the mitotic index.

Hormone assays and physiological attributes. Serum testosterone was estimated using an RIA system standardized and routinely used in the laboratory (Murty et al., 1979). This assay had a sensitivity of $10 \mathrm{pg}$ and the inter- and intraassay variations were of the order of $12.3 \%$ and $5.6 \%$ respectively. Serum FSH was estimated using a solid-phase RIA system developed in the laboratory. This system used cynomolgus monkey FSH as standard (kindly provided by $\mathrm{Dr}$ G. Bialy, NICHD, Bethesda, MD, USA), with $3.0 \mathrm{ng} \mathrm{FSH} / \mathrm{ml}$ sensitivity and inter- and intra-assay variations of the order of $12 \%$ and $9 \%$, respectively.

Collection of semen by electroejaculation and determination of sperm counts were done according to methods described by Mastroianni \& Manson (1963). Testicular volumes were determined using Prader beads.

Statistical analysis of data. All analyses of hormonal and physiological attributes for individual monkeys were performed at least 3 times for each group and the mean \pm s.e.m. values and the means of flow-cytometric data on the percentages of germ cell populations and ratios (Thorud et al., 1980; Toppari et al., 1986) were statistically analysed using Student's $t$ test.

\section{Results}

\section{Physiological and endocrine attributes of sexual maturity}

As shown in Table 1, the body weight and testicular volumes of monkeys aged 3-4 years and 5-6 years were significantly different from each other $(P<0.001)$ and lower $(P<0.01)$ than those of the older age groups. The onset of adulthood, in physical terms, is therefore apparent from 7-8 years onwards. However, the nocturnal testosterone concentration in the 5-6-year-old monkeys was comparable to that seen in adults (Table 1). The 3-4-year-old animals did not exhibit the nocturnal testosterone surge and the values in the evening were significantly $(P<0.001)$ lower than those of all the other groups. The sperm counts of monkeys, first seen in the 5-6-year-old group, were also significantly different from those of the 7-8-year-old $(P<0.05)$ and older $(P<0.01)$ monkeys. The immature monkeys (3-4 years) did not ejaculate. Serum FSH values increased with age, concentrations being significantly lower $(P<0.05)$ in 3-4-year-old than in 5-6- and 7-8-yearold monkeys. However, after 10 years, there was an apparent decline in serum FSH values to attain a steady state.

\section{Histometric analysis}

The 3-4-year-old monkeys did not show any active mitosis but only Sertoli cells and basal spermatogonia with no other cell types (Fig. 1a). Some mitotic activity, greater in some tubules, and occasional spermatozoa were seen in the seminiferous tubules of the 5-6-year-old pubertal group (Fig. 1b). Advanced germ cell types were seen in the 7-8-year-old young adults (Fig. 1c). Monkeys aged 10-14 and 18-20 years showed histological profiles that indicated normal active spermatogenesis (Fig. 1d). Mean testicular biopsy scores and mitotic indices are shown in Table 2.

\section{DNA flow cytometric analysis of germ cells}

Using DNA flow cytometry to distinguish germ cell DNA contents, 5 different populations of germ cells could be identified in the sexually mature adult testis. Their positioning in the flow cytogram was based on the fluorochrome binding to germ cell DNA resulting in fluorescence emission intensities proportional to the DNA contents of cell populations. Since C-values refer to DNA content and ploidies to amount of chromosomes, after locating the $2 \mathrm{C}$ (diploid spermatogonia) 

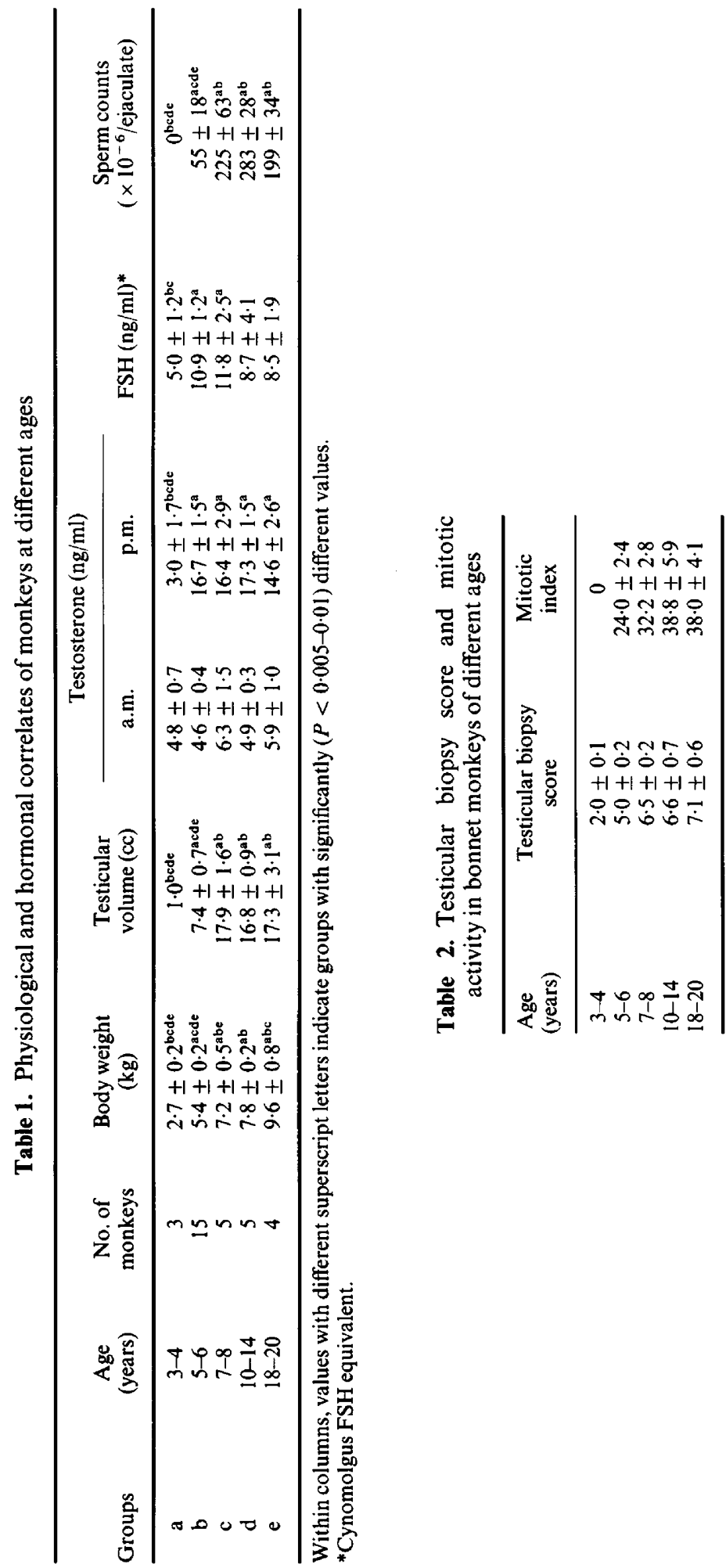
peak using human peripheral blood leucocytes as the $2 \mathrm{C}$ standard, the other major populations were identified according to their relative fluorescence intensities and classified as $4 \mathrm{C}$ (diploid primary spermatocytes), 1C (haploid round spermatids) and apparently hypohaploid HC (haploid elongate spermatids; see 'Discussion'). The HC peak was present only in adult monkeys with mature spermatozoa in their ejaculates.

Representative DNA flow cytograms of testicular germ cells of monkeys from different age groups are presented in Fig. 2 and the percentages of individual populations in Fig. 3. The different cell percentages provided, however, do not add up to 100 as all non-specific fluorescent pulses in the flowcytograms were also quantitated to determine percentages but are not indicated in the histogram (Fig. 3). The 3-4-year-old monkeys exhibited $86.7 \%$ of $2 \mathrm{C}$ cells (Fig. 3), indicating the presence of mostly spermatogonia in the testicular seminiferous tubules (Fig. 2). The onset of active spermatogenesis was apparent in the 5-6-year-old animals with cells in S-phase $(9 \cdot 5 \%), 4 \mathrm{C}$ $(11 \cdot 1 \%), 1 \mathrm{C}(41 \cdot 8 \%)$ and $\mathrm{HC}(17 \cdot 1 \%)$. Compared to these monkeys, significant changes $(P<0.01)$ were observed in the percentages of all the different testicular germ cell types (Fig. 3) in each of the 3 age groups of older monkeys. However, the $1 \mathrm{C}$ values $(45 \cdot 7 \pm 3 \cdot 0 ; 37 \cdot 3 \pm 5 \cdot 8$ and $39 \cdot 3 \pm 2 \cdot 8 \%$, for the 3 groups respectively) did not vary from that of 5-6-year-old animals. Beyond 5-6 years of age the percentage of cells in $2 \mathrm{C}$, S-phase, $4 \mathrm{C}$ and $\mathrm{HC}$ populations did not show any significant changes and the flow cytograms were very similar (Fig. 2).

The ratios of the different populations are presented in Table 3. The ratios could not be calculated for the 3-4-year-old monkeys because their testicular tissue contained only one type of cells, i.e. $2 \mathrm{C}$. The $1 \mathrm{C}: 2 \mathrm{C}$ ratios indicate the overall turnover of cells from spermatogonia up to the round spermatid stage. This ratio, however, can be subdivided into 3 components, $4 \mathrm{C}: 2 \mathrm{C} ; 4 \mathrm{C}: \mathrm{S}$-phase and IC:4C. The 1C:2C values for the $7-8$ and $18-20$-year-old animals were significantly $(P<0.01)$ different from those of 5-6-year-old monkeys. However, the 10-14-year group did not exhibit significant variation, possibly because of the high s.e.m. values. The $4 \mathrm{C}: 2 \mathrm{C}$ and $1 \mathrm{C}: 4 \mathrm{C}$ ratios of monkeys belonging to all the older groups were also significantly $(P<0.05-0.01)$ different from those of the 5-6-year-old monkeys. Although the 4C:S-phase ratios of 10-14- and 18-20-year-old animals were significantly $(P<0.05)$ different from those of the 5-6-year-old group, these ratios for the 7-8 and 18-20 year old groups were similar. The 1C:4C ratios of all the three oldest groups were significantly $(P<0.01)$ different from those of 5-6-year-old monkeys.

\section{Discussion}

In the current study DNA flow cytometry has been used in quantitating the relative testicular germ cell populations in the monkey as a function of sexual maturity. The differentiated germ cell populations with cells in all stages of spermatogenesis is seen for the first time in 5-6-year-old monkeys and this correlates well with physiological characteristics such as testicular volume, hormone profile and the appearance of spermatozoa in the ejaculate that signify onset of sexual maturity. Histological observations showed the presence of primary spermatocytes, round and some elongate spermatids at this age group and there was increased mitotic activity, emergence of S-phase, 4C, IC and some $\mathrm{HC}$ cells in the flow-cytometric profiles. A marked increase in testicular volume after 30 months of age has also been reported for the rhesus monkey (M. mulatta: Bercu et al., 1983) and the crab eating monkey ( $M$. fascicularis: Steiner \& Bremner, 1981). Although testosterone rhythms have been described for most primates including the bonnet monkey (Mukku et al., 1976) the current study suggests that these surges may be involved in promoting spermatogenesis in terms of initiation of transformation of spermatogonia into more advanced cell types as seen at 5-6 years. That this group is still adolescent is evident from the fact that the testicular volumes and testicular biopsy scores are significantly lower than and the germ cell ratios markedly different from those exhibited by older monkeys.

In man (Clausen \& Abyholm, 1980) the flow-cytometrically quantifiable germ cells released from testicular minces can be classified into: (1) $2 \mathrm{C}$-primarily spermatogonial cells in the $\mathrm{Gl}$ 




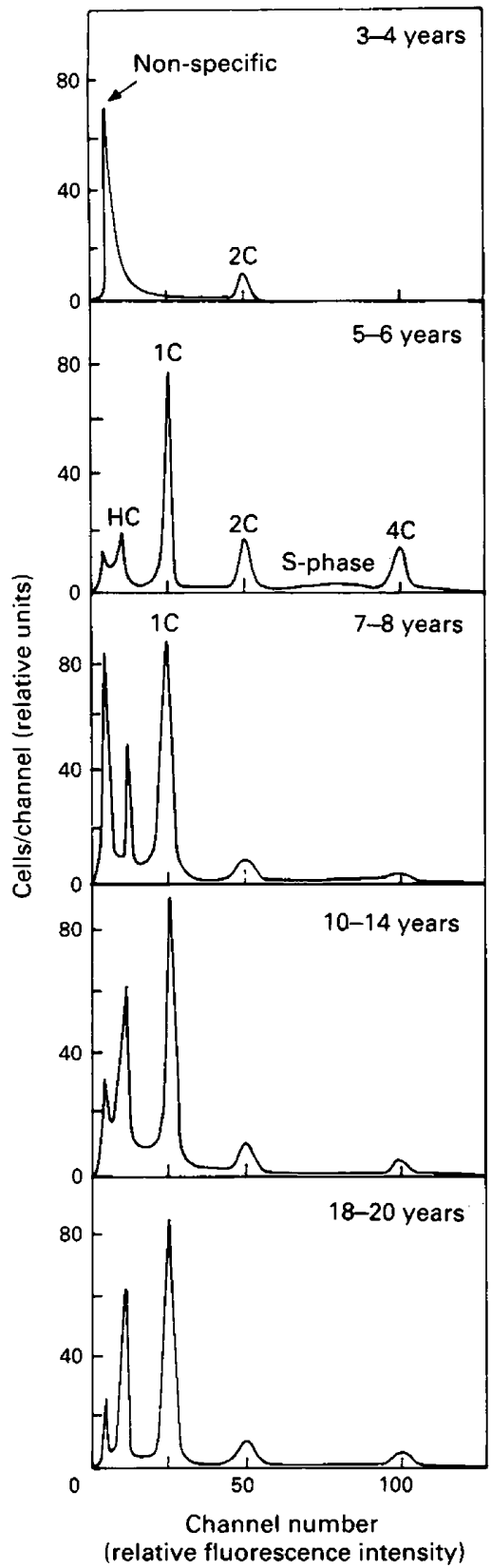

Fig. 2. Characteristic flow cytograms of testicular germ cell populations of monkeys of different age groups.

Fig. 1. Semithin $(0.5 \mu \mathrm{m})$ sections of testis from bonnet monkeys of different age groups $\times 400$. (a) 3-4 years: only Sertoli cells and spermatogonia. (b) 5-6 years: Sertoli cells, spermatogonia, spermatocytes and occasional elongate spermatids are observed. Tubules appear disorganized and characteristic cell associations are ill defined. (c) 7-8 years: normal spermatogenesis with all cell types still with ill defined associations. (d) 10-20 years: well defined germ cell associations and normal spermatogenesis. 


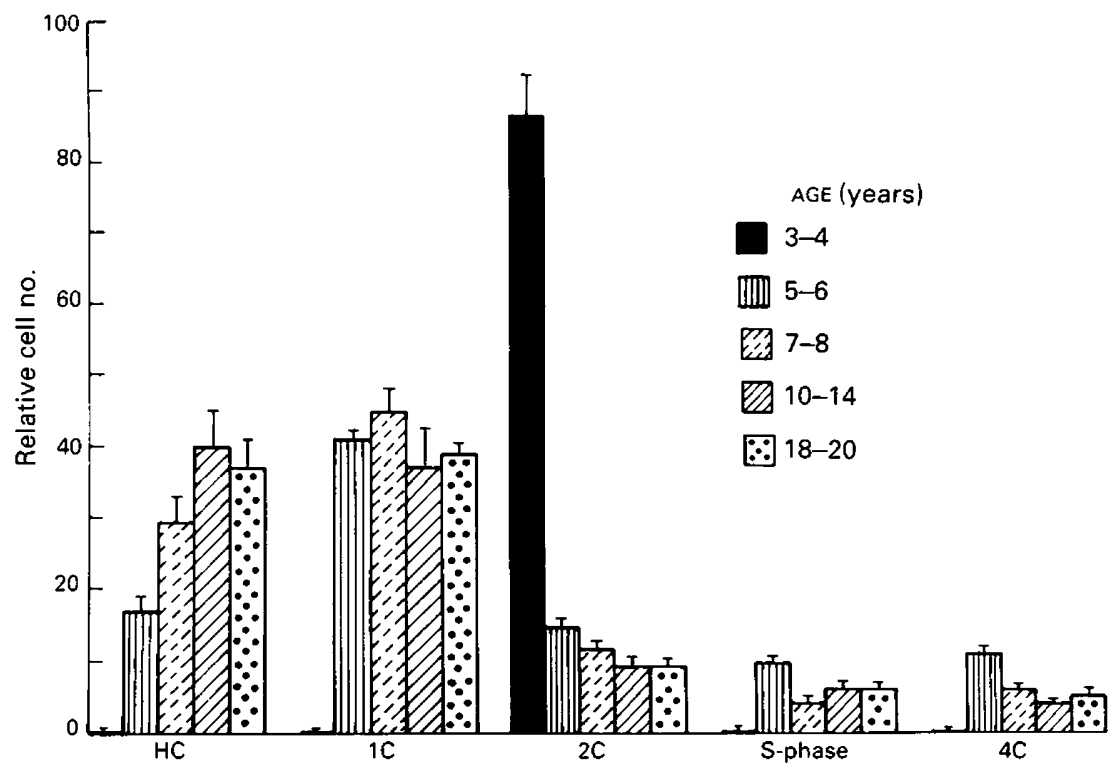

Fig. 3. Histogram depicting the percentages of monkey testicular germ cells quantitated by DNA flow cytometry. Only beyond 10 years of age, these percentages were maintained constant, indicating achievement of steady state spermatogenic kinetics in terms of total cell turnovers. Values are mean \pm s.e.m.

Table 3. Ratios of germ cell populations from monkey testicular biopsies studied using DNA flow cytometry

\begin{tabular}{cccccc}
\hline Age (years) & $1 \mathrm{C}: 2 \mathrm{C}$ & $4 \mathrm{C}: 2 \mathrm{C}$ & $4 \mathrm{C}:$ S-phase & IC:4C & HC: $1 \mathrm{C}$ \\
\hline $3-4 \dagger$ & - & - & - & - & - \\
$5-6$ & $2 \cdot 9 \pm 0 \cdot 2$ & $0 \cdot 8 \pm 0 \cdot 1^{*}$ & $1 \cdot 2 \pm 0 \cdot 1$ & $3 \cdot 8 \pm 0 \cdot 4$ & $0 \cdot 4 \pm 0 \cdot 06$ \\
$7-8$ & $4 \cdot 0 \pm 0 \cdot 3^{* *}$ & $0 \cdot 5 \pm 0 \cdot 1^{*}$ & $1 \cdot 4 \pm 0 \cdot 7$ & $8 \cdot 3 \pm 1 \cdot 2^{* *}$ & $0 \cdot 6 \pm 0 \cdot 1$ \\
$10-14$ & $4 \cdot 2 \pm 1 \cdot 1$ & $0 \cdot 5 \pm 0 \cdot 1^{*}$ & $0 \cdot 7 \pm 0 \cdot 02^{*}$ & $8 \cdot 4 \pm 1 \cdot 0^{* *}$ & $1 \cdot 08 \pm 0 \cdot 3^{*}$ \\
$18-20$ & $4 \cdot 6 \pm 0 \cdot 5^{* *}$ & $0 \cdot 6 \pm 0 \cdot 1^{*}$ & $0 \cdot 9 \pm 0 \cdot 04^{*}$ & $7 \cdot 8 \pm 1 \cdot 0^{* *}$ & $0 \cdot 9 \pm 0 \cdot 2^{*}$ \\
\hline
\end{tabular}

*Significantly $(P<0.05)$ different from values at 5-6 years.

**Significantly $(P<0.01)$ different from values at 5-6 years.

$\dagger$ The germ cell preparations from the biopsies of monkeys from this group had only a $2 \mathrm{C}$ peak rendering calculations of ratios impracticable.

phase; (2) S-phase--preleptotene spermatocytes and some proliferative spermatogonia undergoing DNA synthesis; (3) 4C-leptotene, zygotene, pachytene and diplotene primary spermatocytes and some spermatogonial cells in the G2 phase; (4) 1C-round spermatids; and (5) hypofluorescent (due to hypercondensation of nuclear chromatin) apparently hypohaploid cells referred to here as HC-elongate spermatids. In the present study, the HC peaks observed were positioned exactly coinciding with flow-cytometrically analysed DAPI-stained ejaculated spermatozoa (data not shown), supporting the notion that the HC peak consists of elongate and mature spermatozoa in which the nuclear chromatin has undergone greater compaction. Cell sorting from this peak (Clausen et al., 1982) has revealed it to consist of mature as well as maturing spermatozoa. Furthermore, chemical decondensation of the nuclear chromatin of the compacted HC population caused it to shift to the 1C position (Zante et al., 1977). 
The testicular germ cell distribution in adult bonnet monkeys closely resembles that reported for man with the $1 \mathrm{C}$ population approximating $40 \%$ of the total cells, unlike the $75 \%$ reported for the rat (Clausen et al., 1978b). In contrast to immature (3-4-year-old) monkeys, in which $87 \%$ of the pulses were found in the diploid region (spermatogonial cells), in the immature rat (Clausen et al., 1978a, b; Vaishnav et al., 1988), a flow-cytometrically quantifiable 4C population as well as cells in $\mathrm{S}$-phase in percentages almost similar to the adult have been observed.

By 5-6 years there is a significant reduction $(P<0.001)$ in $2 \mathrm{C}$ values in bonnet monkeys, suggesting that spermatogonia begin active DNA synthesis at this time and are transformed sequentially to pre-leptotene (S-phase, $9 \cdot 5 \%$ ) and primary spermatocytes $(4 \mathrm{C}, 11 \cdot 1 \%)$, round spermatids $(1 \mathrm{C}, 41 \cdot 8 \%)$ and elongate and mature spermatozoa ( $\mathrm{HC}, 17 \cdot 1 \%)$. Histologically, the seminiferous tubules of monkeys of this age revealed disorganization and scattering of the germ cell types with the expected characteristic cell associations being ill defined (Fig. 1b). However, the kinetics of this process appears accelerated (increase in mitotic activity) by the time they attain 7-8 years of age. In this group, therefore, the percentage of cells in $2 \mathrm{C}$, S-phase and $4 \mathrm{C}$ are further reduced compared with those in 5-6-year-old monkeys $(P<0.01)$. Although the percentage of round spermatids appears not to be altered, the $\mathrm{HC}$ population is significantly increased, suggesting an accelerated formation of mature spermatozoa as well as an active replenishment of $1 \mathrm{C}$ cell type. Overall cell transformation from spermatogonia to round spermatids $(1 \mathrm{C}: 2 \mathrm{C}, 4 \cdot 0)$ as well as conversion of $4 \mathrm{C}$ to $1 \mathrm{C}(1 \mathrm{C}: 4 \mathrm{C}, 8 \cdot 3)$ is significantly $(P<0.01)$ increased at $7-8$ years.

Histological examination (Figs $1 \mathrm{~b} \& \mathrm{c}$ ) and morphometric quantitations (Table 2) also revealed higher biopsy scores and mitotic indices for the 7-8-year-old animals. The characteristic germ cell associations are also better defined in this group. As a final end point, significantly $(P<0.01)$ increased sperm output (from $55 \times 10^{6}$ to $225 \times 10^{6}$ ) is observed in the ejaculate (Table 1 ). Although the $\mathrm{HC}: 1 \mathrm{C}$ ratio of 5-6-year-old monkeys $(0 \cdot 4)$ was not significantly different from that of 7-8-year-old animals $(0.6)$, both were significantly lower $(P<0.05)$ than those of the older age groups, suggesting that the rate of transformation of round spermatids into elongate spermatids during spermiogenesis attains maximal efficiency only by 10 years of age.

The endocrine controi of sexual development of the male monkey is not clearly understood. In immature rats FSH is obligatorily required for both spermatogonial proliferation and spermiogenesis (Huckins et al., 1973). FSH deprivation in immature and maturing rats results in a spermatogenic block at the level of primary spermatocytes leading to reduced formation of spermatids (Vaishnav et al., 1988). Bercu et al. (1983) observed no significant increases in FSH concentrations with age (studied between 3 and 60 months of age) in rhesus and crab-eating monkeys but did report the presence of micro- and macropulses of FSH in post-natal and prepubertal monkeys, respectively. Although the need for FSH in sperm production in the primate has been proposed (Murty et al., 1980; Matsumoto et al., 1986; Moudgal et al., 1988; Van Alphen et al., 1988), in the present study, except for a 2-fold increase in serum FSH values between 3-4 and 7-8 years of age, the FSH concentrations did not show marked changes. Whether initiation of spermatogenesis is dependent upon serum FSH or nocturnal testosterone levels or both remains to be established. The reduced $\mathrm{HC}: 1 \mathrm{C}$ ratios observed in the present study in monkeys of younger age groups could be a reflection of the relatively lower serum FSH:testosterone ratios (0.6 at 3-4 years, 1.45 at 5-8 years, 1.85 at $10-20$ years) observed. Monkeys desensitized with GnRH or immunized with FSH show a marked change in this germ cell ratio (unpublished observations).

This work was aided by grants from the Indian Council of Medical Research, New Delhi and the Department of Biotechnology, GOI, New Delhi. We thank Dr N. B. Joshi and Dr B. S. Dwaraknath (NIMHANS, Bangalore) for use of the flow cytometer in their laboratory; Dr T. C. Anand Kumar (Institute for Research in Reproduction, Bombay) for the use of microscopy facilities; and Mr V. Ramesh, Mr H. N. Krishnamurthy and Mrs B. S. Kurkalli for technical assistance. 


\section{References}

Bercu, B.B., Lee, B.C., Pineda, J.L., Spiliotis, B.E., Denman, D.W., III, Hoffman, H.J., Brown, T.J. \& Sachs, H.C. (1983) Male sexual development in the monkey. I. Cross-section analysis of pulsatile hypothalamic-pituitary-testicular function. J. clin. Endocr. Metab. 56, 1214-1226.

Clausen, O.P.F. \& Abyholm, T. (1980) Deoxyribonucleic acid flowcytometry of germ cells in the investigation of male infertility. Fert. Steril. 34, 369-374.

Clausen, O.P.F., Purvis, K. \& Hansson, V. (1978a) Micro-flow fluorometric DNA measurements of isolated testicular cells from the rat. Annls Biol anim. Biochim. Biophys. 18, 541-546.

Clausen, O.P.F., Purvis, K. \& Hansson, V. (1978b) Quantitation of spermatogenesis by flowcytometric DNA measurements. Int. J. Androl., Suppl. 2, 513-521.

Clausen, O.P.F., Purvis, K. \& Hansson, V. (1979) Endocrine correlates of meiosis in the male rat. Archs Androl. 2, 59-66.

Clausen, O.P.F., Parvinen, M. \& Kirkhus, B. (1982) Stage related variations in DNA fluorescence distribution during rat spermatogenic cycle measured by flowcytometry. Cytometry 2, 421-425.

diZerega, G.S. \& Hodgen, G.D. (1980) Changing functional status of monkey corpus luteum. Biol. Reprod. 23, 253-263.

David, G.F.X., Herbert, J. \& Wright, G.D.S. (1973) The ultrastructure of the pineal ganglion in the ferret. $J$. Anat. 115, 79-97.

Evenson, D.P. \& Melamed, M.R. (1983) Rapid analysis of normal and abnormal cell types in human semen and testis biopsies by flowcytometry. J. Histochem. Cytochem. 31, 248-253.

Huckins, C., Mills, N., Besch, P. \& Means, A.R. (1973) Spermatogonial differentiation in immature testis: regulation of FSH. Endocrinology 92, Suppl. 1, 94, abstr.

Johnsen, S.G. (1970) Testicular biopsy score count: a method for registration of spermatogenesis in human testis: normal values and results in 335 hypogonadal patients. Hormones 1, 2-25.

Knobil, E. (1980) The neuroendocrine control of the menstrual cycle. Recent Prog. Horm. Res. 36, 53-88.

Maneckjee, R., Srinath, B.R. \& Moudgal, N.R. (1976) Prolactin suppresses $\mathrm{LH}$ release during lactation in the monkey. Nature, Lond. 262, 507-508.

Mastroianni, L. \& Manson, W.A. (1963) Collection of monkey semen by electroejaculation. Proc. Soc. exp. Biol. Med. 112, 1025-1027.

Matsumoto, A.M., Karpas, A.E. \& Bremner, U.J. (1986) Human chorionic gonadotropin administration in normal men: evidence that follicle stimulating hormone is necessary for the maintenance of quantitatively normal spermatogenesis in man. J. clin. Endocr. Metab. 62, 1184-1192.

Moudgal, N.R., Ravindranath, N., Aravindan, G.R., Dighe, R.R. \& Murthy, G.S. (1988) Anti-FSH antibody as a probe in determining the role of FSH in the maintenance of gonadal function in the primate. In Nonsteroidal Gonadal Factors: Physiological Roles and Possibilities of Contraceptive Development, pp. 249-257. Eds G. D. Hodgen, Z. Rosenwaks \& J. M. Spieler. Jones Institute Press, Norfolk.
Mukku, V.R., Prahalada, S. \& Moudgal, N.R. (1976) Effect of constant light on nycthermeral variations in serum testosterone in male Macaca radiata. Nature, Lond. 260, 778-780.

Murty, G.S.R.C., Sheela Rani, C.S., Moudgal, N.R. \& Prasad, M.R.N. (1979) Effect of passive immunization with specific antiserum to $\mathrm{FSH}$ on the spermatogenic process and fertility of adult male bonnet monkeys (Macaca radiata). J. Reprod. Fert., Suppl. 26, $147-163$.

Murty, G.S.R.C., Sheela Rani, C.S. \& Moudgal, N.R. (1980) The role of $\mathrm{FSH}$ in regulating testicular function-A study involving the use of specific FSH antibodies. In Endocrinology, pp. 162-165. Ed. I. A. Cumming. Elsevier/North Holland, Amsterdam.

Otto, F.J., Oldiges, H., Gohde, W. \& Jain, V.K. (1981) Flowcytometric measurements of nuclear DNA content variations as a potential in vivo mutagenicity test. Cytometry 2, 189-19l.

Otto, F.J., Oldiges, H. \& Jain, V.K. (1984) Flowcytometric measurement of cellular DNA content dispersion induced by mutagenic treatment. In Biological Dosimetry, pp. 37-49. Eds W. G. Eisert \& M. L. Mendelson. Springer-Verlag, Heidelberg.

Prahalada, S., Mukku, V.R., Rao, A.J. \& Moudgal, N.R. (1975). Termination of pregnancy in macaques ( $M$ acaca radiata) using monkey antiserum to ovine luteinizing hormone. Contraception 12, 137-147.

Ravindranth, N. \& Moudgal, N.R. (1987) Use of tamoxifen, an antioestrogen, in establishing a need for oestrogen in early pregnancy in the bonnet monkey (Macaca radiata). J. Reprod. Fert. 81. 327-336.

Steiner, R.A. \& Bremner, W.J. (1981) Endocrine correlates of sexual development in male monkey, Macaca fascicularis. Endocrinology 109, 914-919.

Thorud, E., Clausen, O.P.F. \& Abyholm, T. (1980) Fine needle aspiration biopsies from human testis evaluated by DNA flowcytometry. Acta path. microbiol. scand. (Suppl.) Series A-Flowcytometry IV, 175-177.

Toppari, J., Vihko, K.K., Rasanen, K.G.E., Eerola, E. \& Parvinen, M. (1986) Regulation of stages VI and VIII of rat seminiferous epithelial cycle in vitro. J. Endocr. $108,417-422$.

Toppari, J., Bishop, P.C., Parker, J.W. \& diZerega, G.S. (1988) DNA flowcytometric analysis of mouse seminiferous epithelium. Cytometry 9, 456-462.

Vaishnav, M., Gnanakan, A. \& Moudgal, N.R. (1988) Effect of FSH deprivation of spermatogenesis in the adult rat and monkey: Assessment by DNA flow cytometry. Proc. 8th Int. Congr. Endocrinology, Kyoto, Abstr. 16-18-044.

van Alphen, M.M.A., van de Kant, H.J.G. \& de Rooij, D.G. (1988) Follicle-stimulating hormone stimulates spermatogenesis in the adult monkey. Endocrinology 123, 1449-1455.

van Kroonenburgh, M.J., Van Gasterin, H.J., Beck, J.L. \& Herman, C.J. (1986) A computer model of spermatogenesis in the rat; correlation with flowcytometric data based on autoradiographic cell-cycle properties. Cell Tissue Kinet. 19, 171-177.

Zante, J., Schumann, J., Gohde, W. \& Hacker, V. (1977) DNA flowcytometry of mammalian sperm. Histometry 54, 1-7.

Down loaded from Bioscientifica. com at Received 4 July 1989 